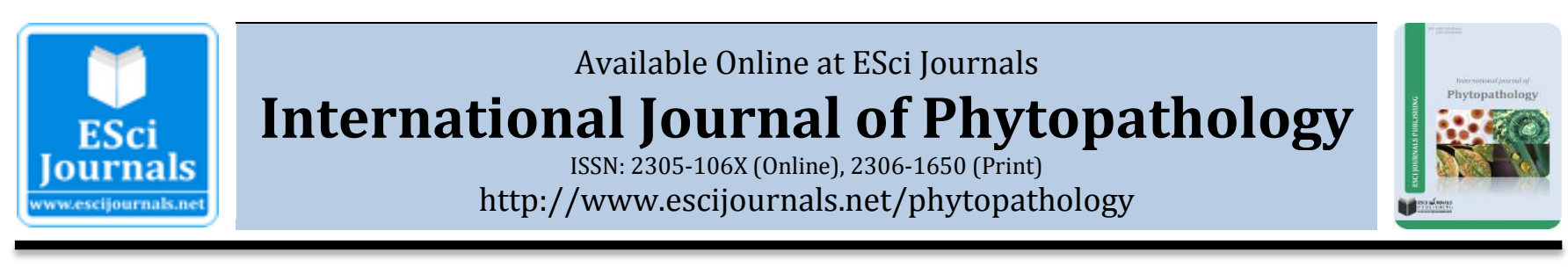

Short Communication

\title{
CCURRENCE OF BLACK MILDEW ON AEGLE MARMELOS AT HIMACHAL PRADESH, INDIA
}

\author{
Ajay K. Gautam \\ Faculty of Agriculture, Abhilashi University, Mandi-175045 (H.P.) India.
}

\begin{abstract}
A B S T R A C T
The leaves of Aegle marmelos were found infected with black mildew during a routine mycological survey at district Bilaspur, a south west region of Himachal Pradesh. Fungal colonies form infected leaves were analysed for morphological and microscopic studies. Nail polish technique was used to study the colonies in situ. Presence of unicellular appressoria with sarciniform and Questieriella conidial anamorphic states identified it as the fungus belongs to genus Schiffnerula. Further investigation identified it as Schiffnerula girijae Hosag. \& Archana. The fungus is reported previously form Thiruvananthapuram, Kerala, India on the same host (A. marmelos) but no reports from other parts of the country. Therefore, this is the second report of black mildew on Aegle marmelos form India while first from north India.
\end{abstract}

Keywords: Black mildew, Aegle marmelos, Schiffnerula girijae, first report, India.

\section{INTRODUCTION}

Aegle marmelos (L.) Correa commonly known as "Bael", is a subtropical tree species belonging to family Rutaceae. Since, the use of leaves, fruits and wood of this plant in numerous religious activities, plant holds a status of "sacred tree" in Indian subcontinent. The plant is native to India and distributed abundantly in Himalayan tract, Bengal, Central and South India. Besides, sacred status, the plant leaves possesses abundant phytochemicals of pharmaceutical importance. The leaves mainly contain alkaloids, phenylpropanoids and terpenoids exhibit anti-inflammatory, antimicrobial, anticancer and anti-oxidative activities (Kirtikar and Basu, 1980; Yadav and Chanotia, 2009). The leaves of Aegle marmelos were found infected with black mildew during a routine mycological survey in October 2013 at district Bilaspur, a south west region of Himachal Pradesh, India with mixed geography i.e. hilly and plainer regions. The fungal pathogen isolated form black mildew infection is described and illustrated in the present paper.

\footnotetext{
* Corresponding Author:

Email: a2gautam2006@gmail.com

(C) 2014 ESci Journals Publishing. All rights reserved.
}

Sample collection and analysis of pathogen: Infected leaf samples were collected with different reproductive parts of $A$. marmelos. Fungal colonies on infected leaves were analysed with the help of hand lenses for morphological studies. Nail polish technique was used to study the colonies in situ. The colonies scraped, mounted in $5 \% \mathrm{KOH}$ solution and then replaced by lactophenol to make the septa visible as given by (Hosagoudar and Kapoor, 1984). The microscopic observations of the fungi were carried out for characteristics of appressoriate mycelium, conidiophores, conidia, thyriothecia, ascus and ascospores.

Disease symptoms and identification of pathogen: The fungal colonies hypophyllous, black coloured, but also appeared on both surfaces; crustose, dense to subdense, coalesced, up to $3 \mathrm{~mm}$ in diameter. Microscopic examination of the colonies revealed substraight to flexuous, reticulates hyphae with opposite branching, septate with cells 12-30 × 5-7.5 $\mu \mathrm{m}$. Appressoria alternate, opposite to unilateral, sessile, globose, ovate, entire, 7.5-12 × 7-11 $\mu \mathrm{m}$. Conidia of Questieriella scattered, pale brown, fusiform, curved, 3septate, and constricted at the septa, tapering towards both ends, 22-35 × 6-8 $\mu \mathrm{m}$. Sarcinella conidiophores 
micronematous, simple, branched, straight to flexuous, pale brown, $0-2$ septate, $8-20 \times 3-8 \mu \mathrm{m}$; conidiogenous cells monoblastic, integrated, mostly terminal, cylindrical; conidia, simple, solitary, subspherical to sarciniform, 2-8-celled, brown when young, carbonaceous black at maturity, sarcinately septate, constricted at the septa, $16-40 \mu \mathrm{m}$ in diameter, wall smooth. Thyriothecia few, orbicular, up to $90 \mu \mathrm{m}$ in diameter; asci globose, octosporous, 16-25 × 11-16 $\mu \mathrm{m}$; ascospores oblong, conglobate, brown, uniseptate, constricted at the septum, $14-22 \times 8-10 \mu \mathrm{m}$, wall smooth (Figure 1).
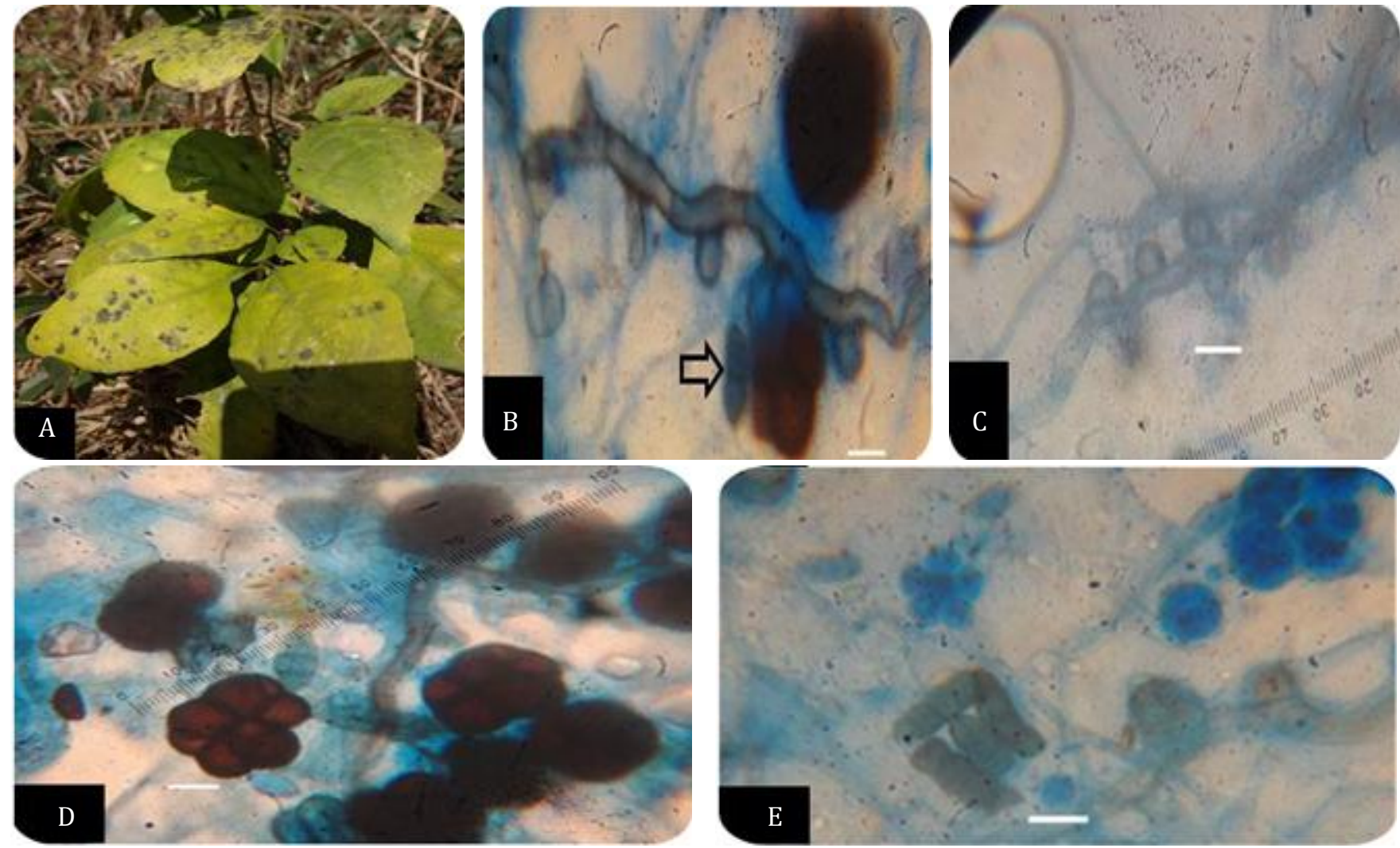

Figure 1. A. Infected leaves. B-C, Appressoriate mycelium, ascospore (arrowed B). D, Sarciniform conidia. E, Spores of Questieriella. Scale bar $=10 \mu \mathrm{m}$

The study revealed the presence of a fungus belongs to genus Schiffnerula. The further observations on unuicellular appressoria with sarciniform and Questieriella conidia identified it as Schiffnerula girijae (Hosag. and Archana, 2010). The fungus identified in present study as Schiffnerula girijae Hosag. \& Archana, is also reported previously form Thiruvananthapuram, Kerala, India on the same host (A. marmelos), but no other available report from any parts of country. The symptoms were described as black colonies on leaves and they are host specific (Hosagoudar, 2011). Therefore, this is the second report of black mildew on Aegle marmelos form India while first from North India. The specimen is deposited at Department of Botany, Abhilashi Institute of Life Sciences (AILS), Mandi, Himachal Pradesh, India for further reference.

\section{REFERENCES}

Hosagoudar, V. B. 2011. The genus Schiffnerula in India. Plant Pathology and Quarantine. 1. 131-204.

Hosagounder, V. B. and Archana, 2010. Schiffnerula girijae. J. Sci. Trans. Technov. 4: 90.

Hosagoudar, V. B. and J. N. Kapoor. 1984. New Technique of mounting Meliolaceous fungi. Indian Phytopathogy. 38. 548-549.

Kirtikar, K. R. and B. D. Basu. 1980. Indian medicinal plants, 2nd edn., M/s Bishen Sing Mahendra Pal Singh, New Connaught Place, Dehra Dun, Vol. 1, 499.

Yadav, N. P. and C. S. Chanotia. 2009. Phytochemical and pharmacological profile of leaves of Aegle Marmelos Linn. The Pharmaceutical Reviews. 144-159. 